\section{Recovery of zinc from copper smelter slag by sulfuric acid leaching in an aqueous and alcoholic environment}

\author{
M.D. Turan ${ }^{1}$, G.A. Karamyrzaev²
} R.K. Nadirov ${ }^{2}$

${ }^{1}$ Firat University, Elazig, Turkey ${ }^{2}$ Institute of Combustion Problems, Almaty, Kazakhstan "E-mail: nadirov.rashid@gmail.com
The content of zinc in copper smelter slags obtained from pyrometallurgical copper production is comparable to the content of this metal in zinc ores. Therefore, these slags are considered a valuable secondary resource for zinc recovery. At the same time, the features of the mineralogical composition of the slag make the extraction of zinc from it very problematic. Most of the zinc is concentrated in the refractory zinc ferrite $\left(\mathrm{ZnFe}_{2} \mathrm{O}_{4}\right)$. To avoid the formation of a viscous pulp when leaching copper smelter slag with an aqueous solution of sulfuric acid, in this work, the slag was leached with sulfuric acid also in isopropanol and n-pentanol, under the following conditions: $0.5 \mathrm{M} \mathrm{H}_{2} \mathrm{SO}_{4}$, pulp density $50 \mathrm{~g} / \mathrm{L}$, magnetic stirrer rotation speed $600 \mathrm{rpm}$. The influence of the duration and temperature of leaching milled $(\leq 100 \mu \mathrm{m})$ copper smelter slag of the Balkhash copper smelter on the extraction of zinc into solution was investigated. It was found that the maximum zinc recovery into an aqueous solution was $75 \pm 2 \%$ at $363 \mathrm{~K}$ and 210 min. Replacing water with isopropanol or n-pentanol led to an increase in zinc recovery to $82 \pm$ $2 \%$ at $210 \mathrm{~min}$ and a lower temperature $(353 \mathrm{~K})$ than in an aqueous environment. An increase in temperature to $383 \mathrm{~K}$ during leaching in $\mathrm{n}$-pentanol made it possible to extract $92 \pm 2 \%$ of zinc. A shrinking core model was used to describe the kinetics of the zinc leaching process. It was found that the limiting stage of the process under all investigated conditions is the chemical leaching reaction. Some kinetic characteristics of the leaching process were calculated, in particular, the apparent reaction rate constants, as well as the activation energy.

Keywords: copper smelter slag; leaching; zinc recovery; isopropanol; n-pentanol.

\section{Су және спирт орталарында күкірт қышқылды сілтілеу арқылы үйінді мыс шлагынан мырышты алу}

М.Д. Туран ${ }^{1}$, Г.А. Карамырзаев ${ }^{2}$ Р.К. Надиров

'Фират Университеті, Элазыг, Түркия ${ }^{2}$ Жану проблемалар институты Алматы, Қазақстан *E-mail: nadirov.rashid@gmail.com
Пирометаллургиялық мыс өндірісінің үйінді мыс шлактарындағы мырыштың құрамы мырыш кендеріндегі осы металдың құрамымен салыстырылады. Сондықтан бұл шлактар мырыш алу үшін құнды ресурс ретінде қарастырылады. Сонымен қатар, шлактың минералогиялық құрамының ерекшеліктері одан мырыш алуды өте проблемалы етеді. Мырыштың негізгі бөлігі мырыш ферритінде $\left(\mathrm{ZnFe}_{2} \mathrm{O}_{4}\right)$ шоғырланған. Үйінді мыс шлагын күкірт қышқылының сулы ерітіндісімен шаймалау кезінде тұтқыр қойыртпақтың пайда болуын болдырмау үшін осы жұмыста қожды күкірт қышқылымен, сондай-ақ изопропанол және н-пентанол ортасында шаймалау жүргізілді, мынадай жағдайларда: 0,5 M H SO қойыртпақтың тығыздығы 50 г/л, магнитті араластырғыштың айналу жылдамдығы 600 айн/ мин. Мырышты ерітіндіге өткізуде Балқаш мыс балқыту зауытының ұсақталған ( $\leq 100$ мкм) үйінді мыс шлагын шаймалау ұзақтығы мен температураның әсері зерттелді. $363 \mathrm{~K}$ және

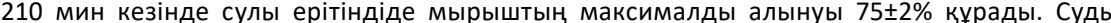
изопропанолмен немесе н-пентанолмен ауыстыру арқылы мырыштың алынуын 210 мин ішінде $82 \pm 2 \%$-ға дейін жоғарлатты және сулы ортаға қарағанда төмен температурада (353 К) алуға мүмкіндік берді. Н-пентанолда шаймалау кезінде температураның 383 К дейін көтерілуі ерітіндіге 92ะ2\% мырыш алуға мүмкіндік берді. Мырышты шаймалау процесінің кинетикасын сипаттау үшін қысқаратын сфера моделі қолданылды. Барлық зерттелген жағдайларда процестің шектеулі кезеңі химиялық шаймалау реакциясы болып табылады. Шаймалау процесінің кейбір кинетикалық сипаттамалары, атап айтқанда реакция жылдамдығының константалары, сондай-ақ активтендіру энергиясы есептелген.

Түйін сөздер: үйінді мыс шлагы; шаймалау; мырыш алу; изопропанол; н-пентанол.

\section{Извлечение цинка из отвального медного шлака сернокислотным выщелачиванием в водной и спиртовых средах}

М.Д. Туран ${ }^{1}$, Г.А. Карамырзаев ${ }^{2}$ P.К. Надиров ${ }^{2^{*}}$

1Университет Фират, Элязыг, Турция ${ }^{2}$ Институт проблем горения, Алматы, Казахстан

*E-mail: nadirov.rashid@gmail.com
Содержание цинка в отвальных медных шлаках пирометаллургического производства меди сопоставимо с содержанием этого металла в цинковых рудах. Поэтому эти шлаки рассматриваются как ценный вторичный ресурс для извлечения цинка. В то же время особенности минералогического состава шлака делают извлечение цинка из него весьма проблематичным. Основная часть цинка сосредоточена в упорном феррите цинка $\left(\mathrm{ZnFe}_{2} \mathrm{O}_{4}\right)$. Во избежание образования вязкой пульпы при выщелачивании отвального медного шлака водным раствором серной кислоты, в настоящей работе проведено выщелачивание шлака серной кислотой также и в среде изопропанола и н-пентанола, при следующих условиях: 0,5 M H SO плотность пульпы 50 г/л, скорость вращения магнитной мешалки 600 об/мин. Исследовано влияние продолжительности и температуры выщелачивания измельченного ( $\leq 100$ мкм) отвального медного шлака Балхашского медеплавильного завода на извлечение цинка в раствор. Найдено, что в водном растворе максимальное извлечение цинка составило $75 \pm 2 \%$ при $363 \mathrm{~K}$ и 210 мин. Замена воды на изопропанол или н-пентанол привела к повышению извлечения цинка до 82+2\% при 210 мин и более низкой температуре (353 K), нежели в водной среде. Повышение температуры до 383 К при выщелачивании в н-пентаноле позволило извлечь $92 \pm 2 \%$ цинка. Для описания кинетики процесса выщелачивания цинка была использована модель сокращающейся сферы. Найдено, что лимитирующей стадией процесса при всех исследованных условиях является химическая реакция выщелачивания. Рассчитаны некоторые кинетические характеристики процесса выщелачивания, в частности, кажущиеся константы скорости реакции, а также энергии активации.

Ключевые слова: отвальный медный шлак; выщелачивание; извлечение цинка; изопропанол; н-пентанол. 


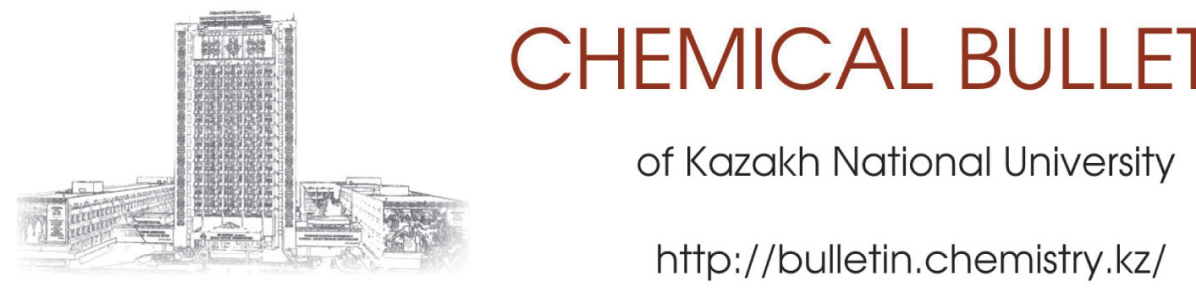

UDC 544.42

https://doi.org/10.15328/cb1244

\title{
Recovery of zinc from copper smelter slag by sulfuric acid leaching in an aqueous and alcoholic environment
}

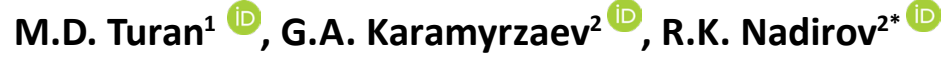 \\ ${ }^{1}$ Firat University, 23119 Elazig Merkez/Elazig, Turkey \\ ${ }^{2}$ Institute of Combustion Problems, 172, Bogenbai Batyr str., Almaty, 480012, Kazakhstan \\ *E-mail: nadirov.rashid@gmail.com
}

\section{Introduction}

Non-ferrous metallurgical slags produced by pyrometallurgical processing of copper concentrates are potential secondary raw materials because they contain a considerable concentration of valuable metals [1-3]. For instance, the content of zinc in copper smelter slag is comparable to that of zinc ores, which makes this slag an attractive resource for zinc recovery [4]. However, the peculiarities of the mineralogical composition of the copper smelter slag make its processing very problematic. Slag is a glassy matrix with a predominance of fayalite $\left(\mathrm{Fe}_{2} \mathrm{SiO}_{4}\right)$, in which the target components, in particular, zinc, are impregnated. Typically, the zinc in the slag is in the form of zinc ferrite $\left(\mathrm{ZnFe}_{2} \mathrm{O}_{4}\right)$, which is a highly stable chemical compound $[5,6]$.

There are several ways to recover zinc from the copper slag. Most of them involve heat treatment of the material by roasting together with ammonium chloride [7], calcium chloride [8], sulfuric acid [9], pyrite [10], as well as ferric sulfate [11]. In some cases, high-temperature reduction of zinc ferrite was used with the release of the target metal in the form of an oxide [12-16]. However, the roasting stages are quite energy-intensive; besides, the risk of air pollution with gaseous products increases.

The most attractive is the hydrometallurgical processing of copper smelter slag with sulfuric acid solutions. The choice of sulfuric acid is due to its production in sufficiently large quantities at non-ferrous metallurgy enterprises, in particular, at copper smelters. The interaction of sulfuric acid with zinc ferrite is described by the following equation [17]:

$$
\mathrm{ZnFe}_{2} \mathrm{O}_{4}+4 \mathrm{H}_{2} \mathrm{SO}_{4}=\mathrm{ZnSO}_{4}+\mathrm{Fe}_{2}\left(\mathrm{SO}_{4}\right)_{3}+4 \mathrm{H}_{2} \mathrm{O}
$$

Despite the negative value of the Gibbs free energy of the above reaction (about $6.7 \mathrm{~kJ} / \mathrm{mol}$ at $298 \mathrm{~K}$ ), its proceeding is very difficult at room temperature due to kinetic limitations; these limitations can be largely eliminated by heating the pulp.

There is one more problem that significantly impedes the hydrometallurgical processing of copper smelter slag. The silicon that has passed into the solution during leaching undergoes polymerization, which makes it very difficult to filter the viscous slurry. This problem can be solved by using nonaqueous solvents. This approach, called solvometallurgical (in contrast to the hydrometallurgical approach, non-aqueous solvents are used here), has been successfully used for leaching non-ferrous, rare and noble metals [18-20]. We have previously described hydrochloric acid leaching of copper smelter slag in isopropyl alcohol for copper recovery [21]. To the best of our knowledge, this article remains the only one in peer-reviewed journals dedicated to the solvometallurgical processing of waste copper slag. In this work, we investigated the process of extracting zinc from copper smelter slag by sulfuric acid leaching in isopropanol, as well as in n-pentanol. The aim of the work was a comparative study of the leaching processes in aqueous and alcoholic environments, as well as the determination of some kinetic parameters of the leaching reaction. Possible reasons for the difference in zinc recoveries, as well as in the values of kinetic parameters, are also discussed in the article.

\section{Experiment}

\subsection{Materials}

Copper smelter slag samples were collected from Balkhash copper smelter (Kazakhstan). The slag was milled and sieved; more than $90 \%$ of slag particles used in leaching experiments were smaller or equal to $100 \mu \mathrm{m}$.

Sulfuric acid (96\%), isopropanol ( $\geq 98 \%)$, and $n$-pentanol $(\geq$ 98\%) purchased from Sigma-Aldrich were used without further purification. 


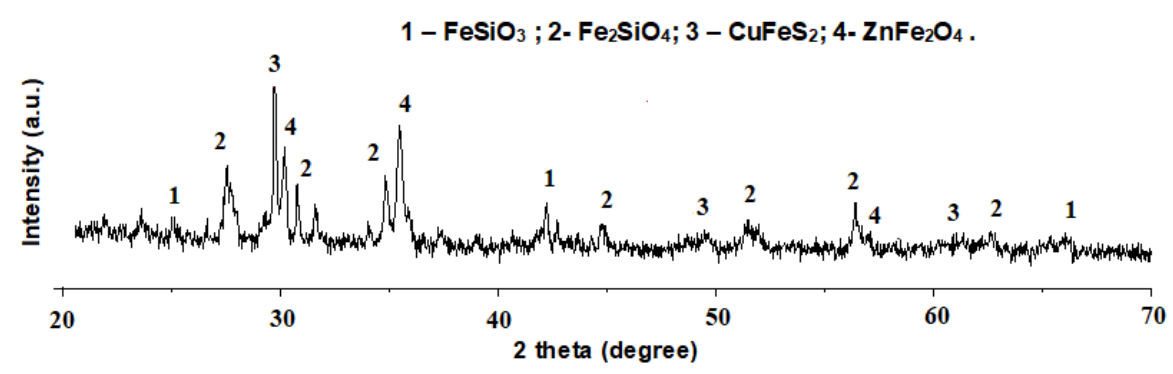

Figure 1 - XRD pattern of the initial slag

\subsection{Leaching experiments}

The batch leaching tests of milled slag with $0.5 \mathrm{M}$ sulfuric acid solution were performed in a $250-\mathrm{mL}$ round-bottom glass thermostated reactor equipped with a magnetic stirrer. Distilled water, isopropanol and n-pentanol were used separately as a solvent. Every $30 \mathrm{~min}$ of leaching, for $210 \mathrm{~min}$, a sample of the solution was taken to determine the zinc content. All the zinc determinations were performed 3 times; mean values of three measurements are presented in Figures. In the Tables, calculated values of standard deviation are also given along with a mean.

\subsection{Characterization}

The elemental composition of the slag sample was determined by inducted coupled plasma atomic emission spectroscopy (ICP-AES, Perkin Elmer, Optima 8000) with preliminary microwave sample decomposition. The content of zinc in liquid samples was also determined by ICP-AES. The XRD pattern was recorded by using a D8 Advance diffractometer (Bruker) with $\alpha$-Cu irradiation ( $40 \mathrm{kV}, 40 \mathrm{~mA})$.

\section{Results and Discussion}

\subsection{Characterization of used slag}

The elemental composition of the copper smelter slag sample determined by atomic emission spectroscopy was as follows, wt \%: Fe 28.7, Si 17.9, Ca 1.8, Zn 4.2, Cu 0.7.

In the slag, fayalite $\left(\mathrm{Fe}_{2} \mathrm{SiO}_{4}\right)$ and ferrosilite $\left(\mathrm{FeSiO}_{3}\right)$ were determined by XRD analysis as major components; zinc ferrite $\left(\mathrm{ZnFe}_{2} \mathrm{SO}_{4}\right)$ and chalcopyrite $\left(\mathrm{CuFeS}_{2}\right)$ were also presented in the sample (Figure 1).

\subsection{Leaching in an aqueous environment}

Figure 2 demonstrates the dependences of the zinc recovery from copper smelter slag into an aqueous solution of sulfuric acid $(0.5 \mathrm{M})$ on the temperature and leaching duration.

The data presented in Figure 2 indicate that an increase in temperature led to an increase in zinc recovery into solution. For all three studied temperatures, an increase in the leaching duration from 30 to $120 \mathrm{~min}$ also led to an increase in the zinc recovery into solution, and this effect slowed down with the course of leaching: in the first $30 \mathrm{~min}$, zinc recovery into solution was 2,16 , and $32 \%$ (hereinafter, the mean values of three measurements are given) for 303,333 and $363 \mathrm{~K}$, respectively, while after $210 \mathrm{~min}$ the recoveries were $5 \pm 1$, $45 \pm 1$, and $75 \pm 2 \%$, respectively. Such a significant effect of temperature on $\mathrm{Zn}$ recovery is because zinc ferrite is very resistant to the action of inorganic acids, in particular, sulfuric acid. Although reaction (1) can be expected even at room temperature on thermodynamic considerations, an acceptable degree of dissolution of zinc ferrite is observed only at elevated temperatures.

The shrinking core model (SCM) that adequately describes the dissolution process of minerals as long as the conversion increases with time was applied in this work for obtaining kinetic characteristics of zinc releasing from copper slag. As a rule, the rate of agitational leaching processes is limited by the chemical reaction of the leaching agent with the mineral surface. We hypothesized that in our case the limiting stage is also a chemical reaction of zinc ferrite with sulfuric acid.

For surface reaction controlled processes the SRM of a mineral leaching can be presented as the following equation (Equation 2):

$$
1-(1-X)^{1 / 3}=k t
$$

where $X$ is the fraction of the target component $(Z n$, in this case) recovered into the solution at the leaching time $t, k$ is the apparent rate constant of the chemical reaction.

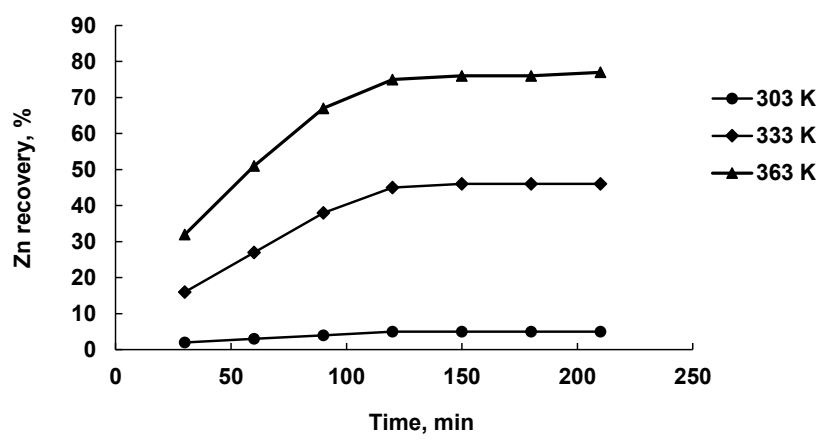

Figure 2 - Effect of leaching duration and temperature on zinc recovery from copper smelter slag into an aqueous solution ( $0.5 \mathrm{M} \mathrm{H}_{2} \mathrm{SO}_{4}$, pulp density $50 \mathrm{~g} / \mathrm{L}, 600 \mathrm{rpm}$ ) 
The $1-(1-X)^{1 / 3}$ plots vs time for three operating temperatures are presented in Figure 3 ; equations of straight lines are also shown.

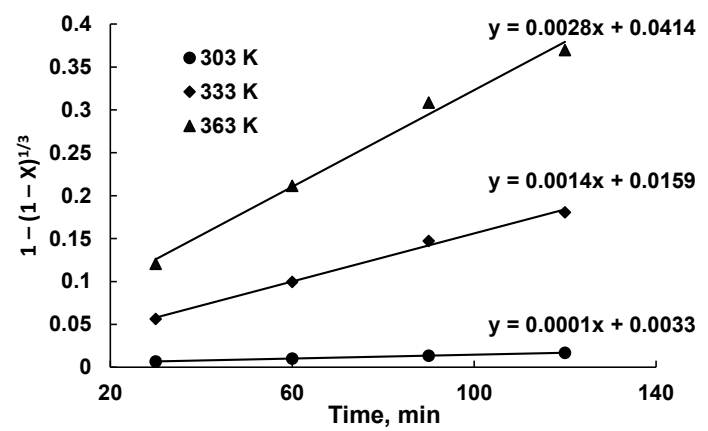

Figure 3 - Plot of $1-(1-X) 1 / 3$ plots vs time for zinc recovery from copper smelter slag into an aqueous solution $(0.5 \mathrm{M}$ $\mathrm{H}_{2} \mathrm{SO}_{4}$, pulp density $50 \mathrm{~g} / \mathrm{L}, 600 \mathrm{rpm}$ )

Since after 120 min of leaching, the zinc recoveries reached a plateau for all temperatures investigated, the recovery values at times over 120 min were not included in Figure 3.

Straight-line dependencies indicate the applicability of SCM for surface reaction controlled processes in describing the process of sulfuric acid leaching of zinc from copper smelter slag. The apparent rate constants for the $\mathrm{Zn}$ releasing from copper smelter slag under the conditions of sulfuric acid leaching were $0.0001,0.0014$, and $0.0028 \mathrm{~min}^{-1}$ at 303, 333, and $363 \mathrm{~K}$, respectively (see equations of straight lines in Figure 3).

\subsection{Leaching in an alcohol environment}

The dependences of the zinc recovery from copper smelter slag into an isopropanol solution of sulfuric acid (0.5 M) on the temperature and leaching duration are shown in Figure 4. Due to the low boiling point of isopropanol (about $355 \mathrm{~K}$ ), leaching was carried out at 303,333 and $353 \mathrm{~K}$.

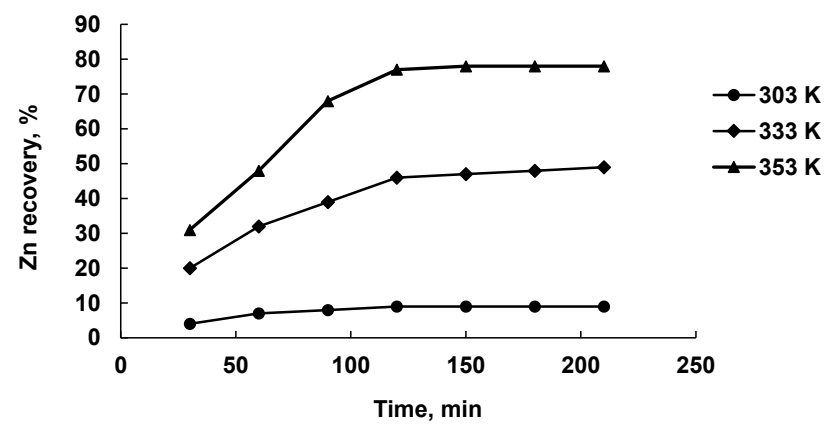

Figure 4 - Effect of leaching duration and temperature on zinc recovery from copper smelter slag into isopropanol solution ( $0.5 \mathrm{M} \mathrm{H}_{2} \mathrm{SO}_{4}$, pulp density $50 \mathrm{~g} / \mathrm{L}, 600 \mathrm{rpm}$ )
As it was observed for aqueous solutions, with increasing leaching duration, $\mathrm{Zn}$ recovery demsonstrated an upward trend up to 120-150 min for all investigated temperatures; at the same time, $\mathrm{Zn}$ recovery in the case of an isopropanol solution was higher than in aqueous solution, at 303 and $333 \mathrm{~K}$. The $\mathrm{Zn}$ recoveries at $353 \mathrm{~K}$ in an isopropanol solution and $363 \mathrm{~K}$ in an aqueous solution were approximately at the same level, which indicates a favourable role of isopropyl alcohol in the leaching of $\mathrm{Zn}$ from slag.

The $1-(1-X)^{1 / 3}$ plots vs time for $\mathrm{Zn}$ sulfuric acid leaching in isopropanol solution are presented in Figure 5.

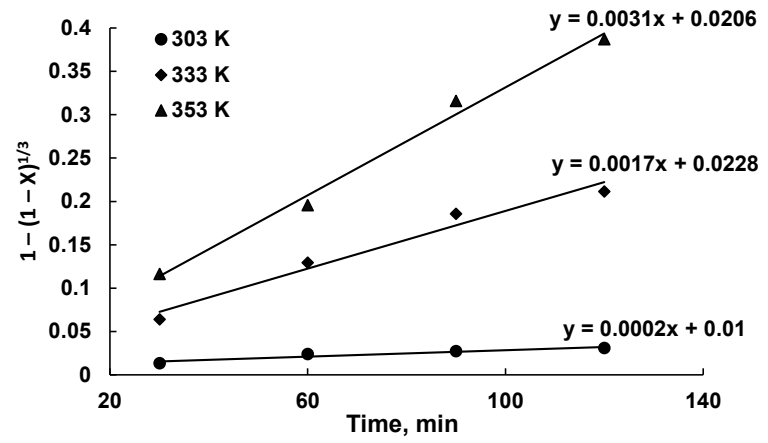

Figure 5 - Plot of $1-(1-X)^{1 / 3}$ vs time for zinc recovery from copper smelter slag into isopropanol solution $\left(0.5 \mathrm{M} \mathrm{H}_{2} \mathrm{SO}_{4^{\prime}}\right.$ pulp dzensity $50 \mathrm{~g} / \mathrm{L}, 600 \mathrm{rpm}$ )

Linear dependences $1-(1-X)^{1 / 3}$ vs time also testify in favour of kinetic control of the $\mathrm{Zn}$ leaching process, as in the case of leaching in an aqueous solution. However, the apparent rate of constants at 333 and $363 \mathrm{~K}$ in an alcoholic medium is 1.2-2.0 times higher than in an aqueous one; moreover, apparent rate constant at $353 \mathrm{~K}$ in isopropanol environment is about 1.1 times higher than that obtained in aqueous solution.

To study the effect of the alcohol chain length on $\mathrm{Zn}$ releasing from copper slag, leaching tests using $n$-pentanol were performed. Despite the high boiling point of $n$-pentanol (about $411 \mathrm{~K}$ ), the upper limit for leaching was set at $353 \mathrm{~K}$, to correctly compare the results of leaching in isopropanol and n-pentanol. Zn recoveries, as well as apparent rate constants at three investigated temperatures, are presented in Table 1.

Comparison of the data in Table 1 with those in Figures 4 and 5 reveals that replacing isopropanol with $n$-pentanol did not lead to any noticeable changes in zinc recovery, taking into account the experimental error; the values of apparent rate constants of leaching reaction also remained the same level.

Since $\mathrm{n}$-pentanol has a much higher boiling point than isopropanol ( $411 \mathrm{~K}$ vs $355 \mathrm{~K}$ ), it seemed informative to perform leaching in $\mathrm{n}$-pentanol at elevated temperatures. Table 2 shows the effect of leaching duration and temperature on zinc recovery from copper smelter slag into $n$-pentanol solution $\left(0.5 \mathrm{M} \mathrm{H}_{2} \mathrm{SO}_{4}\right.$, pulp density $50 \mathrm{~g} / \mathrm{L}, 600 \mathrm{rpm}$ ) at the temperatures of 363,383 and $403 \mathrm{~K}$. 
Table 1 - Effect of leaching duration and temperature on zinc recovery from copper smelter slag into n-pentanol solution (0.5 M $\mathrm{H}_{2} \mathrm{SO}_{4}$, pulp density $50 \mathrm{~g} / \mathrm{L}, 600 \mathrm{rpm}$ ) and apparent rate constants of leaching reaction

\begin{tabular}{ccccccccc}
\hline \multirow{2}{*}{$\begin{array}{c}\text { Temperature, } \\
\text { K }\end{array}$} & \multicolumn{9}{c}{ Zn recovery (\%) at leaching duration, min } & \multicolumn{2}{c}{$\begin{array}{c}\text { Apparent rate constant of } Z n \\
\text { leaching reaction, } \text { min }^{-1}\end{array}$} \\
\cline { 2 - 7 } & 30 & 60 & 90 & 120 & 150 & 180 & 210 & 0.0002 \\
303 & $6 \pm 1$ & $8 \pm 1$ & $10 \pm 1$ & $11 \pm 1$ & $12 \pm 1$ & $12 \pm 1$ & $12 \pm 1$ & 0.0017 \\
353 & $23 \pm 1$ & $35 \pm 1$ & $43 \pm 1$ & $49 \pm 1$ & $50 \pm 1$ & $51 \pm 1$ & $52 \pm 1$ & 0.0031 \\
\hline
\end{tabular}

Table 2 - Effect of leaching duration and temperature on zinc recovery from copper smelter slag into n-pentanol solution (0.5 M $\mathrm{H}_{2} \mathrm{SO}_{4}$, pulp density $50 \mathrm{~g} / \mathrm{L}, 600 \mathrm{rpm}$ ) at elevated temperatures

\begin{tabular}{cccccccc}
\hline \multirow{2}{*}{$\begin{array}{c}\text { Temperature, } \\
\text { K }\end{array}$} & 30 & 60 & 90 & 120 & 150 & 180 & 210 \\
\cline { 2 - 8 } & $35 \pm 1$ & $54 \pm 1$ & $73 \pm 2$ & $84 \pm 2$ & $87 \pm 2$ & $87 \pm 2$ & $87 \pm 2$ \\
363 & $41 \pm 1$ & $63 \pm 1$ & $79 \pm 2$ & $89 \pm 2$ & $91 \pm 1$ & $91 \pm 2$ & $91 \pm 2$ \\
403 & $42 \pm 1$ & $64 \pm 2$ & $80 \pm 2$ & $89 \pm 2$ & $91 \pm 2$ & $92 \pm 2$ & $92 \pm 2$ \\
\hline
\end{tabular}

It can be seen that raising the leaching temperature generally increased the zinc recovery into solution. The maximum extraction of zinc at $383 \mathrm{~K}$ was $91 \%$ vs $82 \%$ at $353 \mathrm{~K}$. Noteworthy is the fact that an increase in temperature from 383 to $403 \mathrm{~K}$ practically did not change the $\mathrm{Zn}$ recovery. This led to the fact that the rate constants of the leaching reaction at both temperatures mentioned were the same $\left(0.0031 \mathrm{~min}^{-1} \mathrm{vs}\right.$ $0.0029 \mathrm{~min}^{-1}$ at $363 \mathrm{~K}$ ). For the subsequent construction of the dependence $1 / \mathrm{T}-\ln \mathrm{k}$ (not shown) to determine the activation energy $\left(E_{A}\right)$ of the zinc leaching reaction, the slag was leached at $373 \mathrm{~K}$. The reaction rate constant was $0.0030 \mathrm{~min}^{-1}$.

Table 3 shows the calculated activation energies for the zinc leaching reaction under various conditions described in this work.

Comparison of the activation energies of zinc leaching shows that the use of isopropanol and $n$-pentanol reduced the activation energy of the main reaction of zinc leaching from the slag (reaction 1). Elgersma et al [22] demonstrated that the activation energy of sulfuric acid leaching (aqueous solution, $0.5 \mathrm{M} \mathrm{H}_{2} \mathrm{SO}_{4}$ ) of synthetic zinc ferrite is $74 \pm 2 \mathrm{~kJ} / \mathrm{mol}$, in the temperature range of $75-95^{\circ} \mathrm{C}$. The lower value of the activation energy in our case $(51 \pm 1 \mathrm{~kJ} / \mathrm{mol})$ can be explained as follows. In the copper smelter slag, zinc is not only in the form of zinc ferrite but also in the form of more reactive compounds (sulfides and oxides). Due to their low content, these compounds were not detected by XRD analysis. Sulfuric acid leaching reactions of these compounds have lower activation energies than zinc ferrite leaching; it is this circumstance that reduces the energy activation of the whole process of zinc recovery.

A favourable effect on the leaching of minerals in alcoholic solvents in comparison with an aqueous environment was observed in several works [23-26]. In particular, the positive effect of ethanol on hydrochloric leaching of scheelite was explained by the better solvating ability of this alcohol concerning chloride ions [25]. Jana et al showed that in hydrochloric acid solutions of some alcohols, in particular, in methanol and ethanol, the activity of chloride ions increases; this circumstance led to an increase in the leaching efficiency of sea nodules [26].

We assume that as the proton is hydrogen-bonded to alcohols (i.e. $\mathrm{C}_{3} \mathrm{H}_{7} \mathrm{OH}_{2}{ }^{+}$and $\mathrm{C}_{5} \mathrm{H}_{11} \mathrm{OH}_{2}{ }^{+}$in our case) alcohol can be considered to be a good cationic collector. Therefore, solvated protons are more active than hydrated ones (in aqueous solution), which increases the efficiency of leaching in an alcohol environment. The Gibbs free energy of protons solvation in alcohol is lower than that of proton hydration in aqueous solutions [27]. This indicates a higher concentration of

Table 3 - Activation energies of $\mathrm{Zn}$ leaching reaction under different conditions

\begin{tabular}{cccc}
\hline & & \multicolumn{2}{c}{ Leaching conditions } \\
\cline { 2 - 4 } & $\begin{array}{c}\text { Aqueous solution } \\
(303-363 \mathrm{~K})\end{array}$ & $\begin{array}{c}\text { Isopropanol solution } \\
(303-353 \mathrm{~K})\end{array}$ & $\begin{array}{c}\mathrm{N} \text {-pentanol solution } \\
(303-353 \mathrm{~K})\end{array}$ \\
\hline $\begin{array}{c}\text { Activation energy }\left(\mathrm{E}_{\mathrm{A}}\right), \\
\mathrm{kJ} / \mathrm{mol}\end{array}$ & $51 \pm 1$ & $42 \pm 1$ & $42 \pm 1$ \\
\hline
\end{tabular}


hydronium ions in alcoholic environment than in aqueous one at the same acid concentration. Since the protonation of the surface of zinc ferrite with hydronium ions is an obligatory stage of its leaching [22], replacing water with alcohol as a solvent has a favorable effect on the leaching process. This argument is in good agreement with that described by Jana et al [26].

The sharp decrease in the activation energy during leaching in n-pentanol in the temperature range of $363-383 \mathrm{~K}$ is explained by a change in the mechanism of slag leaching at elevated temperatures. In this case, a change in temperature within the above limits has practically no effect on the degree of zinc recovery and the rate of the process.

3.4 Economic feasibility of using alcohols in copper smelter slag leaching

Despite the higher cost of alcohols in comparison with the cost of water, the possible use of alcohols, in particular isopropanol or $n$-pentanol, for leaching copper slag seems to be justified. First, the use of a non-aqueous environment avoids the formation of a hard-to-filter slurry due to the polymerization of silicic acid in an aqueous solution. This aspect is very important and determines the advantages of solvometallurgy over hydrometallurgy. Secondly, the use of alcohol as a solvent makes it possible to increase the extraction of zinc into solution. After processing the solution, the alcohol can be reused for leaching. Thus, the prospects for using alcohol as a solvent in copper slag leaching appear to be favorable.

\section{Conclusions}

Isopropanol and $\mathrm{n}$-pentanol are demonstrated to be feasible solvents for sulfuric acid leaching of zinc from copper smelter slag. The dissolution rate of zinc-containing minerals, predominantly zinc ferrite $\left(\mathrm{ZnFe}_{2} \mathrm{O}_{4}\right)$, was increased with increasing leaching duration and temperature in all three investigated solvents, including water, isopropanol and $\mathrm{n}$-pentanol. The zinc recovery into solution during leaching with $0.5 \mathrm{M} \mathrm{H}_{2} \mathrm{SO}_{4}$ in alcohol environment was $82 \pm 2 \%$ at $210 \mathrm{~min}$ and $353 \mathrm{~K}$, while in an aqueous solution it was possible to extract only $75 \pm 2 \%$ at $363 \mathrm{~K}$ and the same leaching duration. An increase in temperature to $383 \mathrm{~K}$ during leaching in $\mathrm{n}$-pentanol increased zinc recovery to $92 \pm 2 \%$. According to XRD analysis, the main zinc-containing compound in the slag was zinc ferrite; at the same time, the relatively low value of the activation energy during leaching in an aqueous solution indicates the presence of other, more reactive zinc minerals in the slag. The results obtained indicate that the use of aliphatic alcohols, in particular, isopropanol and n-pentanol, is promising for the sulfuric acid leaching of zinc from copper smelter slag.

\section{Acknowledgements}

This research was funded by the Science Committee of the Ministry of Education and Science of the Republic of Kazakhstan (Grant No. AP08856414).

\section{References (GOST)}

1 Tian H., Guo Z., Pan J., Zhu D., Yang C., Xue Y., Wang D. Comprehensive review on metallurgical recycling and cleaning of copper slag // Resources, Conservation and Recycling. - 2021. -Vol.168. - ID105366.

2 Phiri T.C., Singh P., Nikoloski A.N. The potential for copper slag waste as a resource for a circular economy: A review-Part II // Minerals Engineering. - 2021. - Vol.172. - ID107150.

3 Mikula K., Izydorczyk G., Skrzypczak D., Moustakas K., Witek-Krowiak A., Chojnacka K. Value-added strategies for the sustainable handling, disposal, or value-added use of copper smelter and refinery wastes // Journal of Hazardous Materials. - 2021. - Vol.403. - ID123602.

4 Zhang S., Zhu N., Mao F., Zhang J., Huang X., Li F., Dang Z. A novel strategy for harmlessness and reduction of copper smelting slags by alkali disaggregation of fayalite $\left(\mathrm{Fe}_{2} \mathrm{SiO}_{4}\right)$ coupling with acid leaching // Journal of Hazardous Materials. - 2021. - Vol.402. - ID123791.

5 Li Y.C., Zhuo S.N., Peng B., Min X.B., Liu H., Ke Y. Comprehensive recycling of zinc and iron from smelting waste containing zinc ferrite by oriented transformation with $\mathrm{SO}_{2} / /$ Journal of Cleaner Production. - 2020. - Vol.263. - ID121468.

6 Wang Z., Zhao Z., Zhang L., Liu F., Peng B., Chai L., Liang Y. Formation mechanism of zinc-doped fayalite $\left(\mathrm{Fe}_{2-\mathrm{x}} \mathrm{Zn}_{\mathrm{x}} \mathrm{SiO}_{4}\right)$ slag during copper smelting // Journal of hazardous materials. - 2019. - Vol.364. - P.488-498.

7 Nadirov R.K., Syzdykova L.I., Zhussupova A.K., Usserbaev M.T. Recovery of value metals from copper smelter slag by ammonium chloride treatment // International Journal of Mineral Processing. - 2013. - Vol.124. - P.145-149.

8 Guo X., Zhang B., Wang Q., Li Z., Tian Q. Recovery of zinc and lead from copper smelting slags by chlorination roasting // JOM. - 2021. - Vol.73, Is.6. - P.1861-1870.

9 Nadirov R.K. Recovery of valuable metals from copper smelter slag by sulfation roasting // Transactions of the Indian Institute of Metals. - 2019. - Vol.72, Is.3. - P.603-607.

10 Tümen F., Bailey N.T. Recovery of metal values from copper smelter slags by roasting with pyrite // Hydrometallurgy. - 1990. - Vol.25, Is.3. - P.317-328.

11 Altundoğan H. S., Tümen F. Metal recovery from copper converter slag by roasting with ferric sulphate // Hydrometallurgy. 1997. - Vol.44, Is.1-2. - P.261-267. 
12 Lee J.J., Lin C.I., Chen H.K. Carbothermal reduction of zinc ferrite // Metallurgical and Materials Transactions B. - 2001. Vol.32, Is.6. - P.1033-1040.

13 Kazemi M., Sichen D. Investigation of selective reduction of iron oxide in zinc ferrite by carbon and hydrogen // Journal of Sustainable Metallurgy. - 2016. - Vol.2, Is.1 - P.73-78.

14 Wang Z., Liang Y., Peng N., Peng B. The non-isothermal kinetics of zinc ferrite reduction with carbon monoxide // Journal of Thermal Analysis and Calorimetry. - 2019. - Vol.136, Is.5. - P.2157-2164.

15 Junca E., Grillo F.F., Restivo T.A.G., de Oliveira J.R., Espinosa D.C.R., Tenório J.A.S. Kinetic investigation of synthetic zinc ferrite reduction by hydrogen // Journal of Thermal Analysis and Calorimetry. - 2017. - Vol.129, Is.2. - P.1215-1223.

16 Chen Y., Wang Y., Peng N., Liang Y., Peng B. Isothermal reduction kinetics of zinc calcine under carbon monoxide // Transactions of Nonferrous Metals Society of China. - 2020. - Vol.30, Is.8. - P.2274-2282.

17 Sarma V.N.R., Deo K., Biswas A.K. Dissolution of zinc ferrite samples in acids // Hydrometallurgy. - 1976. - Vol.2, Is.2. - P.171184.

18 Binnemans K., Jones P.T. Solvometallurgy: an emerging branch of extractive metallurgy // Journal of Sustainable Metallurgy. - 2017. - Vol.3, Is.3. - P.570-600.

19 Li X., Monnens W., Li Z., Fransaer J., Binnemans K. Solvometallurgical process for extraction of copper from chalcopyrite and other sulfidic ore minerals // Green Chemistry. - 2020. - Vol.22. - No.2. - P.417-426.

20 Orefice M., Binnemans K. Solvometallurgical process for the recovery of rare-earth elements from Nd-Fe-B magnets // Separation and Purification Technology. - 2021. - Vol.258. - P.117800.

21 Nadirov R., Turan M. D., Karamyrzayev G.A. Copper smelter slag leaching with hydrochloric acid in isopropyl alcohol: kinetic study // International Journal of Biology and Chemistry. - 2020. - Vol.13, Is.2. - P.141-146.

22 Elgersma F., Kamst G.F., Witkamp G.J., Van Rosmalen G.M. Acidic dissolution of zinc ferrite // Hydrometallurgy. - 1992. Vol.29, Is.1-3. - P.173-189.

23 Solís-Marcial O.J., Lapidus G.T. Study of the dissolution of chalcopyrite in sulfuric acid solutions containing alcohols and organic acids // Electrochimica Acta. - 2014. - Vol.140. - P.434-437.

24 Girgin I.., Erkal F. Dissolution characteristics of scheelite in $\mathrm{HCl}-\mathrm{C}_{2} \mathrm{H}_{5} \mathrm{OH}-\mathrm{H}_{2} \mathrm{O}$ and $\mathrm{HCl}-\mathrm{C}_{2} \mathrm{H}_{5} \mathrm{OH}$ solutions // Hydrometallurgy. 1993. - Vol.34, Is.2. - P.221-229.

25 Trifoni M., Toro L., Veglio F. Reductive leaching of manganiferous ores by glucose and $\mathrm{H}_{2} \mathrm{SO}_{4}$ : effect of alcohols // Hydrometallurgy. - 2001. - Vol.59, Is.1. - P.1-14.

26 Jana R.K., Singh D.D.N., Roy S.K. Alcohol-modified hydrochloric acid leaching of sea nodules // Hydrometallurgy. - 1995. Vol.38, Is.3. - P.289-298.

27 Marković Z., Tošović J., Milenković D., Marković S. Revisiting the solvation enthalpies and free energies of the proton and electron in various solvents // Computational and Theoretical Chemistry. - 2016. - Vol.1077. - P.11-17.

\section{References}

1 Tian H, Guo Z, Pan J, Zhu D, Yang C, Xue Y, Wang D (2021) Resour Conserv Recy 168:105366. https://doi.org/10.1016/j. resconrec.2020.105366

2 Phiri TC, Singh P, Nikoloski AN (2021) Miner Eng 172:107150. https://doi.org/10.1016/j.mineng.2021.107150

3 Mikula K, Izydorczyk G, Skrzypczak D, Moustakas K, Witek-Krowiak A, Chojnacka K (2021) J Hazard Mater 403:123602.

4 Zhang S, Zhu N, Mao F, Zhang J, Huang X, Li F, Dang Z (2021) J Hazard Mater 402:123791. https://doi.org/10.1016/j. jhazmat.2020.123791

5 Li YC, Zhuo SN, Peng B, Min XB, Liu H, Ke Y (2020) J Clean Prod 263:121468. https://doi.org/10.1016/j.jclepro.2020.121468

6 Wang Z, Zhao Z, Zhang L, Liu F, Peng B, Chai L, Liang Y (2019) J Hazard Mater 364:488-498. https://doi.org/10.1016/j. jhazmat.2018.10.071

7 Nadirov RK, Syzdykova LI, Zhussupova AK, Usserbaev MT (2013) Int J Miner Process 124:145-149. https://doi.org/10.1016/j. minpro.2013.07.009

8 Guo X, Zhang B, Wang Q, Li Z, Tian Q (2021) JOM-US 73 (6):1861-1870. https://doi.org/10.1007/s11837-021-04680-4

9 Nadirov RK (2019) T Indian I Metals 72(3):603-607. https://doi.org/10.1007/s12666-018-1507-5

10 Tümen F, Bailey NT (1990) Hydrometallurgy 25(3):317-328. https://doi.org/10.1016/0304-386X(90)90047-6

11 Altundoǧan H S, Tümen F (1997) Hydrometallurgy 44(1-2):261-267. https://doi.org/10.1016/S0304-386X(96)00038-2

12 Lee JJ, Lin Cl, Chen HK (2001) Metall Mater Trans B 32(6):033-1040. https://doi.org/10.1007/s11663-001-0092-9

13 Kazemi M, Sichen D (2016) J Sustain Met 2(1):73-78. https://doi.org/10.1007/s40831-015-0037-1

14 Wang Z, Liang Y, Peng N, Peng B (2019) J Therm Anal Calorim 136(5):2157-2164. https://doi.org/10.1007/s10973-018-7841-3

15 Junca E, Grillo FF, Restivo TAG, de Oliveira JR, Espinosa DCR, Tenório JAS (2017) J Therm Anal Calorim 129(2):1215-1223. https://doi.org/10.1007/s10973-017-6222-7 
16 Chen Y, Wang Y, Peng N, Liang Y, Peng B (2020) T Nonferr Metal Soc 30(8):2274-2282. https://doi.org/10.1016/S10036326(20)65378-X

17 Sarma VNR, Deo K, Biswas AK (1976) Hydrometallurgy 2(2):171-184. https://doi.org/10.1016/0304-386X(76)90026-8

18 Binnemans K, Jones PT (2017) J Sustain Met 3(3):570-600. https://doi.org/10.1007/s40831-017-0128-2

19 Li X, Monnens W, Li Z, Fransaer J, Binnemans K (2020) Green Chem 22(2):417-426. https://doi.org/10.1039/c9gc02983d

20 Orefice M, Binnemans K (2021) Sep Purif Technol 258:117800. https://doi.org/10.1016/j.seppur.2020.117800

21 Nadirov R, Turan MD, Karamyrzayev GA (2020) Int J Biol Chem 3(2):141-146. https://doi.org/10.26577/ijbch.2020.v13.i2.16

22 Elgersma F, Kamst GF, Witkamp GJ, Van Rosmalen GM (1992) Hydrometallurgy 29(1-3):173-189. https://doi.org/10.1016/0304386X(92)90012-O

23 Solís-Marcial OJ, Lapidus GT (2014) Electrochim Acta 140:434-437. https://doi.org/10.1016/j.electacta.2014.07.041

24 Girgin I, Erkal F (1993) Hydrometallurgy 34(2):221-229. https://doi.org/10.1016/0304-386X(93)90036-D

25 Trifoni M, Toro L, Veglio F (2001) Hydrometallurgy 59(1):1-14. https://doi.org/10.1016/S0304-386X(00)00138-9

26 Jana RK, Singh DDN, Roy SK (1995) Hydrometallurgy 38(3):289-298. https://doi.org/10.1016/0304-386X(94)00069-F

27 Marković Z, Tošović J, Milenković D, Marković S (2016) Comput Theor Chem 1077:11-17. https://doi.org/10.1016/j. comptc.2015.09.007 